\title{
Review \\ An Analysis of the Intellectual Property Market in the Field of Enhanced Oil Recovery Methods
}

\author{
Violetta A. Vasilenko ${ }^{1}$ (D, Vasili A. Vasilenko ${ }^{1}$, Evgenia A. Skichko ${ }^{1}$, Dmitriy A. Sakharov ${ }^{2}$, Ruslan R. Safarov ${ }^{3}$, \\ Mariia G. Gordienko ${ }^{3, *}$ and Andrei V. Oleinik ${ }^{4}$ \\ 1 Department of Informational Computing Technologies, D. Mendeleev University of Chemical-Technology of \\ Russia, 9, Miusskaya sq., 125047 Moscow, Russia; vavasilenko@muctr.ru (V.A.V.); vvavva@muctr.ru (V.A.V.); \\ skichkoevgeniya@muctr.ru (E.A.S.) \\ 2 Rector's Office, D. Mendeleev University of Chemical-Technology of Russia, 9, Miusskaya sq., \\ 125047 Moscow, Russia; sakharov@muctr.ru \\ 3 Science-Research Department, D. Mendeleev University of Chemical-Technology of Russia, 9, Miusskaya sq., \\ 125047 Moscow, Russia; safarov@muctr.ru \\ 4 Department of Management and Informatics in Technical Systems, Moscow State University of Technology \\ STANKIN, 3A, Vadkovsky lane, 127055 Moscow, Russia; a.oleynik@stankin.ru \\ * Correspondence: gordienko@muctr.ru; Tel.: +7-903-751-9120
}

check for updates

Citation: Vasilenko, V.A.; Vasilenko, V.A.; Skichko, E.A.; Sakharov, D.A.; Safarov, R.R.; Gordienko, M.G.; Oleinik, A.V. An Analysis of the Intellectual Property Market in the Field of Enhanced Oil Recovery Methods. Designs 2021, 5, 1. https://doi.org/10.3390/designs 5010001

Received: 28 November 2020 Accepted: 18 December 2020 Published: 2 January 2021

Publisher's Note: MDPI stays neutral with regard to jurisdictional clai$\mathrm{ms}$ in published maps and institutional affiliations.

Copyright: (C) 2021 by the authors. Licensee MDPI, Basel, Switzerland. This article is an open access article distributed under the terms and conditions of the Creative Commons Attribution (CC BY) license (https:// creativecommons.org/licenses/by/ $4.0 /)$.

\begin{abstract}
The article presents an analysis of the intellectual property market in the field of enhanced oil recovery (EOR) methods. The search retrospectively covers the period from 2010 to 2020. Russia, China, and the United States are the leading countries in enhanced oil recovery methods. Canada, Germany, and Saudi Arabia also have a high level of patent activity compared with other countries. Semantic and statistical analysis of the obtained sample of documents made it possible to highlight the areas of intensive patenting, high competitiveness, as well as mainstream methods of enhanced oil recovery. The analysis of the leading companies' patent portfolios revealed the similarities and differences in their structure. Tatneft, ConocoPhillips Co., Sinopec, and PetroChina Co. are actively patenting in the field of thermal enhanced oil recovery, which has been identified as the mainstream. BASF SE is focused on the production of chemicals, including chemicals for oil production. The Saudi Arabian Oil Company produces light oil using waterflooding and physicochemical methods. Software dominates the patent collection sector in the EORs of Gazpromneft STC and Lukoil.
\end{abstract}

Keywords: enhanced oil recovery; intellectual property market; patenting intensity; mainstream EOR methods

\section{Introduction}

Oil is a mineral, which is an oily liquid composed of a mixture of hydrocarbons and other organic compounds. Oil serves as a source of a large number of types of modern fuels-kerosene, gasoline, diesel fuel, diesel fuel, etc. [1-3]. In addition, oil after processing is actively used in the chemical industry as a raw material for the production of household chemicals, medicines, cosmetics, plastic, and plastic products, as well as in the production of rubber, rubber, paints, varnishes, wax, etc. [4-9]. The list of products that are produced from oil is endless, even waste oil is used to make coke in the industry [10-12].

Despite the growing popularity among developed countries of the "green economy" and other environmentally friendly types of production, oil is still the backbone of the current global economy. Figure 1 shows the volume of crude oil production from 2010 to 2019, as reported in the BP report [13].

The data presented allow us to speak of a slowdown in the growth rates of the oil industry and a plateau. The main oil suppliers are the countries of the Middle East and North America. Let us analyze the volumes of oil production in these regions by the incoming countries. Figure 2 a shows the distribution of oil production by the countries of 
the Middle East for the period from 2010 to 2019 (the leader is Saudi Arabia), and Figure 2b by the countries of North America (the leader is the United States) [13].

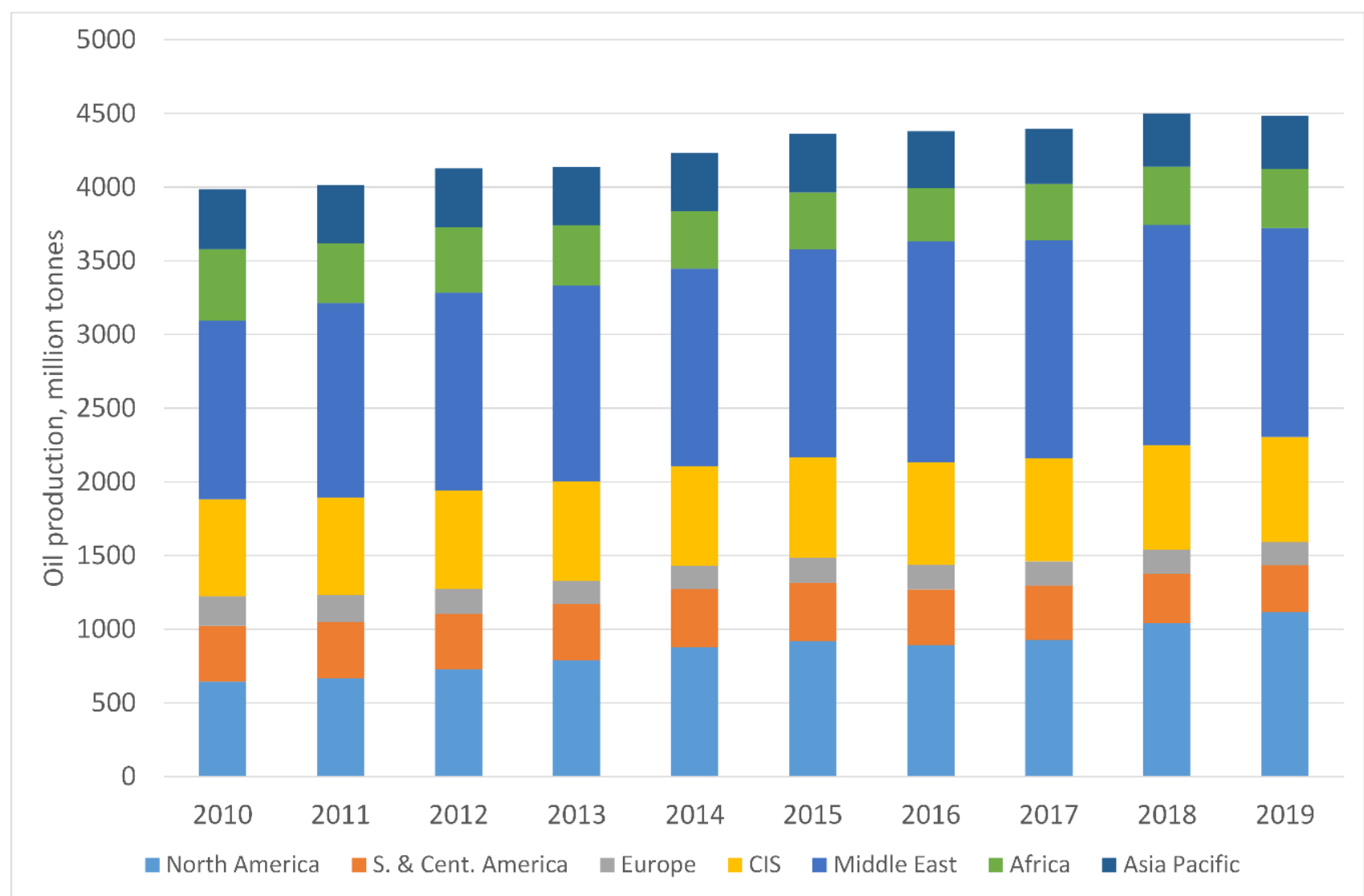

Figure 1. Volumes of crude oil production from 2010 to 2019 by country.

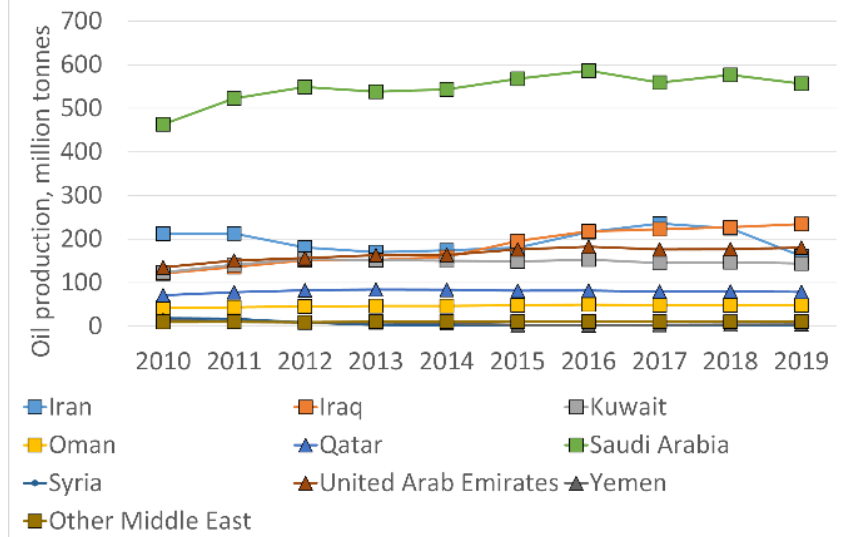

(a)

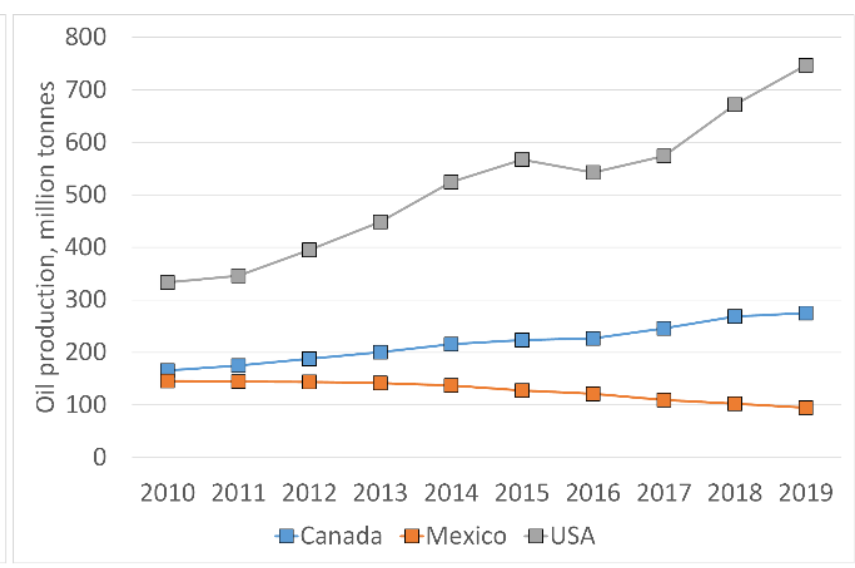

(b)

Figure 2. Volumes of oil production for the period from 2010 to 2019 in the countries of the regions: (a) the Middle East; (b) North America.

It can be noted that the volumes of oil production by the countries of the Middle East are maintained at the same level, whereas the United States and Canada (North America) are increasing oil production. This is due to the "shale revolution" launched by the United States $[14,15]$. Canada is the second country to see large-scale development of shale resources, which already account for $8 \%$ of total Canadian oil production $[16,17]$. 
It should be noted that taking into account the current rate of extraction of available global hydrocarbon reserves, their rapid depletion can be predicted; in particular, the projected time of exhaustion of crude oil is about 50 years, including (in billion barrels of oil): Venezuela-302, Saudi Arabia-297, Iran-211.6, Canada-170.5, Iraq-142.5, Kuwait-101.5, UAE—97.8, Russia-80, Libya-48, and Nigeria-37 [18].

The undisputed world leader in terms of the size of the oil resource base is Saudi Arabia, where a sixth of the world's liquid hydrocarbon reserves have been explored in the depths of 80 fields. The country's oil resource base is of exceptional quality: deposits of light low-sulfur oil are located at shallow depths, forming unique and large deposits located in favorable geographical and mining-geological conditions [19]. All this makes it possible to operate with high productivity, which provides one of the lowest production costs in the world and delivery of oil to the consumer. Despite the reduction in liquid fuel production in 2016-2017 in accordance with the OPEC+ limitation agreement, the share of Saudi Arabia in world production reached $12.7 \%$, and daily production exceeded 9.97 million barrels [20-23].

Russian proven reserves of liquid hydrocarbons is about $5 \%$ of the world. In 2017, daily domestic production reached 11 million barrels per day, and the country's share was $14 \%$ of global production [18].

The United States completes the list of top three oil producers with reserves much smaller than those of Saudi Arabia (only 35.4 billion barrels), although production has almost doubled in five years, to 9.2 million barrels per day in 2017 [18]. This was achieved thanks to the continuous improvement of technologies for the development of shale deposits [24-26].

Almost all oil in the world is produced from terrigenous and carbonate reservoirs. There are voids in the rock-pores, cracks or cavities in which oil accumulates. These voids can be located in sandstones or under wind-blown rock fragments - these are terrigenous reservoirs. Light oil is extracted from them. Since 2008, the production of "light" oil has been steadily declining. Therefore, the most promising technological trends include the development of technologies for extracting unconventional and hard-to-recover hydrocarbon reserves.

Carbonate reservoirs - the second most abundant in the world - are formed mainly from the remains of a variety of marine organisms, such as corals and plankton. They remain in the same place where they once lived, and retain a much more complex structure due to their biogenic origin and the processes that occur with them at depth. Quite often, as a result of tectonic processes, cracks appear in carbonate strata. They can penetrate the porous framework of the reservoir in different directions, dividing it into blocks. In such cases, a double medium is formed, which is represented by pore blocks that contain oil and a network of fractures along which it is transported. In these two types of cavities, the movement of oil obeys different laws, so the presence of a dual environment complicates the development. In addition, cracks and pores in such a rock may not communicate with each other or have low permeability, which makes it very difficult to extract oil from such depths.

The term "hard-to-recover reserves" appeared in the 1970s, and it refers to reserves contained in geological formations, the features of which do not allow the organization profitable oil production using existing technologies. Hard-to-recover reserves include oil reserves in low-permeability reservoirs, high-viscosity oil, residual reserves of depleted fields, as well as gas cap deposits. In addition, the list of hard-to-recover reserves usually includes unconventional reserves, as well as deposits in remote and hard-to-reach areas. To extract such oil profitably requires new and expensive methods (compared with traditional methods of development), technologies, and logistics solutions [27-33].

Indicators such as viscosity, density, resin and paraffin content are key classification criteria when classifying oil samples as hard to recover [34-40]. Complicated conditions include well operating conditions with factors that impede production. These include low gas saturation of the formation; increased amount of mechanical impurities; a large amount 
of salts and resin-paraffin fractions; oils with abnormal physical properties; reservoirs with heterogeneity in permeability; reservoirs with low initial oil saturation; low formation temperature in combination with other factors [41-47].

The main problems in the production of hard-to-recover oils can be divided into three groups: the presence of paraffins in oil, low porosity, and poor permeability of rocks in bedding conditions, which complicate the physical properties of the fluid [48-55].

Paraffins in oil are in a dissolved state under reservoir conditions. When it moves along the elevator, paraffins are deposited on the walls of the well, forming paraffinic plugs, thereby creating many technological and technical tasks for oilmen to eliminate them. The paraffinic deposits themselves are a complex hydrocarbon physicochemical mixture, which includes, in fact, paraffins, asphalt-resinous compounds, silica gel resins, oils, water, and mechanical impurities. A decrease in pressure, temperature, and oil degassing to a greater extent affects the intensity of deposits. Various methods are used to combat paraffin deposits; for example, they can add the use of scrapers (mechanical method), the introduction of chemical compounds into an oil emulsion (chemical method), or the effect of a heat source on the fluid (thermal methods) [56-61].

Porosity is the ability of rocks to contain liquid or gaseous hydrocarbons, expressed as the ratio of the free space of the rock to its total volume. The larger the pore channels, the more hydrocarbons they contain. Porosity depends on the grain-size composition of the rock, its heterogeneity, and the ratio of the number of large and small pores, and it usually decreases with increasing depth of the rocks.

Permeability is a filtration parameter of a rock, characterizing its ability to transmit oil, gas, and water to the bottom of wells. Permeability is influenced by pore sizes and pressure drops in oil reservoirs. The phase composition of the fluid also has a significant impact on the permeability. Low values of these parameters make it difficult for the fluid to move to the bottom [62-64].

High viscosity and density are properties that can significantly increase the cost of oil production. They make it difficult for the fluid to move to the bottom and down the wellbore. When extracting heavy and high-viscosity oils, specialized technologies are used to reduce the values of these parameters [65-68].

In general, the production of hard-to-recover oils is a global task of the modern oilproducing industry, the solution of which requires analytical, scientific, and engineering approaches are in order to make it possible to identify the most effective method of enhanced oil recovery for a particular well. Crude oil production differs depending not only on the geographic location of the field but also on the duration of its development. The oil industry is forced to be proactive by constantly developing new technologies. Analysis of patent information in the field of enhanced oil recovery will provide an insight into the main trends in the oil industry.

\section{Relevance, Goals, and Stages of Intellectual Property Analysis in the Field of Enhanced Oil Recovery}

The law defines intellectual property as intangible rights that protect creations of the human mind and intelligence, divided into two categories: industrial property (inventions (patents), trademarks, industrial designs and geographical indications of origin) and copyright (literary and artistic works, musical works, works of fine art, architectural structures). It should be noted that the concepts of applicant or author are not equivalent to the concept of patent holder. When conducting this study, the authors took into account the patent holders. International intellectual property law ensures the creation of a working environment in which innovation is valued and creativity is encouraged as well as the possibility of settling disputes that may arise during the signing of contracts and agreements on cooperation by market participants as a result of mergers and acquisitions of companies.

Intellectual property is an essential asset for innovative and large commercial organizations. Intellectual property rights allow customers to distinguish an organization by attributing certain qualities to its products and services. Large companies are actively registering and acquiring intellectual property in order to gain competitive advantage 
in emerging national and international markets. Companies that are patent holders are increasingly incorporating the rental of intellectual property into their business processes. This approach contributes to the growth of the intellectual property market. A limiting factor for the growth of the intellectual property market is the high cost of copyrights and licenses, especially in the case of obtaining international rather than national patents.

The analysis of intellectual property in the field of enhanced oil recovery methods included the following stages:

1. Collection and statistical analysis of patent documents in the field of enhanced oil recovery (distribution of found documents by countries that issued a patent; dynamics of publication activity). The patent search was carried out using keywords and predefined international classification classes.

2. Semantic analysis of patents (frequency analysis and definition of the terms most often found in titles and abstracts of documents) and definition of areas of high intensity of patenting, high competition.

3. Analysis of the dynamics of patent activity for various aspects of search (aspects of search were selected in accordance with the international patent classification) and definition of mainstream technologies in the field of enhanced oil recovery.

4. Identification of key patent holders in the field of enhanced oil recovery methods and a brief description of their patent collections, including compliance with mainstream trends, areas of high patenting intensity and high competition.

In the following sections, the analysis steps and the obtained results are discussed in detail.

\section{Patent Search: Methodology and Statistics of the Obtained Data Set}

The analytical materials presented in the study were obtained on the basis of information about registered patent applications and issued patents published by patent offices of all countries of the world. Compared with scientific publications, patent information contains a mandatory detailed technological description of the novelty of the proposed technological solution or product.

In this study, the patent family (many publications related to one invention) was selected as a unit of analysis in order to eliminate duplication of information, discrepancies arising from translation of patent information from different languages.

When forming the sample, we used a semantic search for related patent documents, research of information from specialized companies, and a search in selected categories of the international patent classification. The categories of the international patent classification were selected taking into account the specifics of the area under consideration-methods of enhanced oil recovery.

The search was carried out on the following databases: Espacenet [69], World Intellectual Property Organization, WIPO [70], Federal Institute of Industrial Property, FIPS [71], and Google Patents [72]. The search retrospective was 10 years.

An analysis of global trends in patenting technologies for the increase of oil recovery, considering the last 10 years, revealed more than 1500 patents (1633). In recent years, the leading countries (country of issue of the patent) in this field are Russia, China, and the United States; other key countries include Canada, Germany, and Saudi Arabia. All other countries have significantly lower patent activity than the leading ones (Figure 3). 


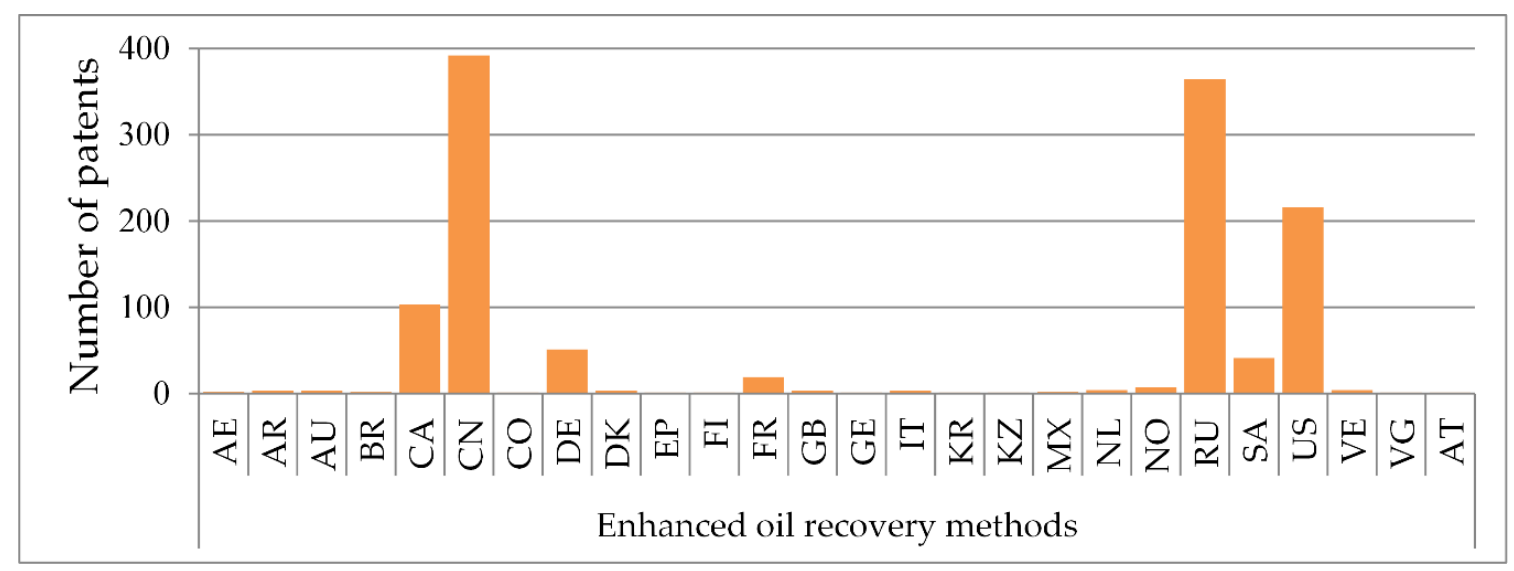

Figure 3. Distribution of the number of patent documents on enhanced oil recovery methods for the period 2010-2020 by country.

One of the basic analytical concepts for conducting research on global patenting trends in this area is the distribution of the number of publications by year (Figure 4).

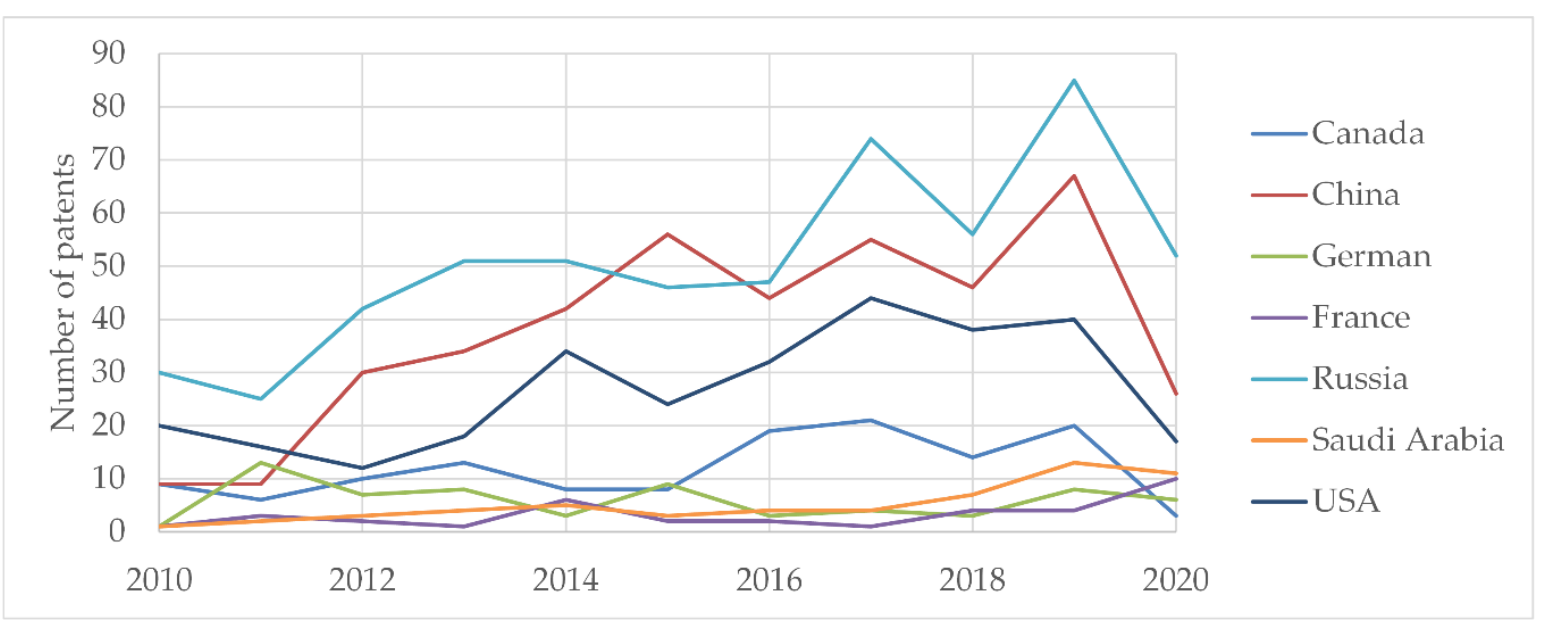

Figure 4. Dynamics of publication activity on enhanced oil recovery methods in key countries of the industry.

Figure 4 shows the dynamics of patent activity of applicants and allows us to assess the interest of companies in developing methods for enhanced oil recovery in key countries of the industry. The lower number of documents in 2020 is due to the fact that documents for the period of only 8 months were taken into account, as well as delays in publishing data in bulletins and databases. Geographical coverage analysis provides an insight into a countries' territorial strategies for enhanced oil recovery, the most promising markets, cases of international cooperation, and technology development from the point of view of individual countries and regions.

Analysis of the dynamics of patent activity in the leading countries allows us to identify three leading countries in terms of the number of publications over the time period under review: the Russian Federation, China, and the United States.

Russia is a leader in patenting enhanced oil recovery methods, but Russian developers prefer to work with the Federal Institute of Industrial Property rather than with international agencies. It should be noted that the dominant part of patents issued in the Russian Federation have the status of national patents. In Russia, there is a gradual increase in publication activity, with a slight drop in 2015-2016 and in 2018. The largest number of patents is registered in 2019, although the results for the first 8 months of 2020 indicate a continued increase in publication activity in Russia in the field of enhanced oil recovery. On average, the patenting period for an invention in Russia is 1.5 years. 
In China, there is a gradual increase in publication activity, with a slight drop in 2016 and 2018. The most active publication period is 2019. The period between the consideration of an application and the issuance of a patent takes relatively shorter periods (from 6 months to a year).

In the U.S. collection segment, the publication activity is ambiguous, accompanied by fluctuations over the years. Nevertheless, there was a general upward trend until 2017, followed by a slight decline. In the United States, the interval between consideration of an application and the issuance of a patent takes from 1 to 1.5 years.

Analysis of the patent activity of the three leading countries allows us to conclude that the intellectual property market in the field of enhanced oil recovery methods has not yet stabilized. This is primarily due to the fact that conditionally available deposits are gradually thinning, and it is necessary to develop deposits located in hard-to-reach areas, which, for example, for the Russian Federation include the coastal zone and its shelf. Such developments require significant investments and, in some cases, the modernization of fixed assets. Despite global trends in the field of ecology, oil remains one of the most popular energy resources. All this leads to the search for new technological solutions in the direction of enhanced oil recovery methods.

As noted in the analysis of Figure 3, in addition to the three leading countries, Canada, Germany, Saudi Arabia, and France can also be distinguished.

The dynamics of patent activity in Canada almost repeats the U.S. activity. This is characterized by close trade and scientific cooperation between the two countries. Nevertheless, the Canadian segment of collection is almost 2 times smaller.

The maximum patent activity in Germany took place in 2011. Then there are fluctuations with a downward trend in patent activity. At the same time, in 8 months of 2020, more patents were found than in 2014 and 2016-2018, which indicates an increase of interest in the direction of enhanced oil recovery methods.

As for patent activity in the segments of Saudi Arabia and France (Figure 3), there is a significant growth in the number of documents for these countries, and in the case of France, the largest number of documents during last 10 years was received in 8 months of 2020.

The analysis of patent dynamics in the direction of enhanced oil recovery methods for the countries considered, excluding 2020, allows us to conclude that the intellectual property market in this area has not yet stabilized and it is possible to search for new technological solutions that will be in demand. It should be noted that the leaders in the number of their own developments are Russia, China, the United States, and Canada.

\section{Areas of High Patenting Intensity and High Competitiveness}

Semantic analysis of the documents allowed us to identify the most frequently encountered terms that were used for technological clustering and to determine the main objects of patenting. Statistical analysis of documents taking into account the objects of patenting allowed us to distinguish two areas: the area of high intensity of patenting and the area of high competition.

Table 1 shows data on technological clustering in the field of enhanced oil recovery when analyzing the collection of patent documents for the period 2010-2020 for the area of intensive patenting. The most intensive areas of patenting are the following enhanced oil recovery methods: "flooding" (hydrodynamic method); "hydraulic fracturing" (mechanical method); thermal methods, including "steam-thermal impact on the reservoir" and "superheated water vapor injection"; and physical and chemical methods. It should also be noted that there is a fairly large number of documents related to the mathematical modeling of processes occurring during oil recovery. 
Table 1. Technological clustering in the field of enhanced oil recovery in 2010-2020 for the area of intensive patenting.

\begin{tabular}{cc}
\hline The Subject & Number of Patents \\
Flooding & 250 \\
Hydraulic fracturing treatment & 179 \\
Steam-thermal impact on the reservoir & 123 \\
Mathematical models of processes occurring during oil recovery & 120 \\
Superheated water vapor injection & 114 \\
Acid treatment & 109 \\
Injection of surface-active substances & 108 \\
In situ combustion & 70 \\
Surfactants & 68 \\
Thermal methods for increasing oil well productivity & 38 \\
Software based on mathematical models & 38 \\
Injection of polymer systems & 35 \\
Other subject & 30 \\
\hline
\end{tabular}

Table 2 shows data on technological clustering in the direction of enhanced oil recovery methods in 2010-2020, split between key countries for the area of high competition.

Leaders in the field of hydrodynamic methods ("flooding") are China (121 patents), followed by the Russian Federation (74 patents) and the United States (20 patents). Among mechanical methods ("hydraulic fracturing"), China and the Russian Federation have almost the same number of patents (67 and 60, respectively). The United States has half as many -36 patents. Leaders patenting of thermal methods of enhanced oil recovery, in particular methods such as the injection of superheated steam and thermal steam stimulation, are the United States, Canada, Russia, and China, possessing an almost equal number of patents. In the field of chemical methods (acid treatment), the leaders are the Russian Federation (51 patents) and the United States (19 patents).

Table 2. Technological clustering in the direction of enhanced oil recovery methods in 2010-2020 split between key countries for a highly competitive area.

\begin{tabular}{|c|c|c|c|c|c|c|c|}
\hline The Subject of the Search (The Object of Study and Its Constituent Parts) & CA & $\mathrm{CN}$ & DE & FR & RU & SA & US \\
\hline Flooding & 3 & 121 & 6 & 5 & 74 & 12 & 20 \\
\hline Hydraulic fracturing treatment & 13 & 67 & - & 1 & 60 & 1 & 36 \\
\hline Steam-thermal impact on the reservoir & 26 & 28 & 1 & - & 33 & 2 & 30 \\
\hline Mathematical models of processes occurring during oil recovery & 1 & 22 & - & 7 & 58 & 2 & 27 \\
\hline Superheated water vapor injection & 34 & 4 & 2 & 1 & 22 & - & 44 \\
\hline Acid treatment & 1 & 8 & 4 & 3 & 51 & 3 & 35 \\
\hline Injection of surface-active substances & 3 & 14 & 21 & 5 & 34 & 6 & 19 \\
\hline Thermal methods for increasing oil well productivity & 3 & 52 & 1 & - & 10 & 1 & 3 \\
\hline Gasifiers & 4 & 1 & - & 1 & 45 & - & 15 \\
\hline Surfactant & 4 & 4 & - & 2 & 14 & 7 & 7 \\
\hline In situ combustion & 2 & 2 & 1 & - & 22 & - & 7 \\
\hline Software based on mathematical models & 2 & 2 & - & 3 & 19 & 1 & 6 \\
\hline Injection of polymer systems & - & 3 & 1 & 3 & 7 & 8 & 4 \\
\hline
\end{tabular}

In the field of physical and chemical methods, the leaders are Russia (34 patents), Germany (21 patents), and the United States (19 patents). In the field of thermogasochemical methods, the Russian Federation is the leader (45 patents). The United States has almost half as many (19 patents). 


\section{The Mainstream Technologies in the Field of Enhanced Oil Recovery Methods}

In order to assess the potential contribution of science and technology to achieving competitive advantage in promising markets, the entire sample of patent documents was divided into subsets in accordance with the International Patent Classification (IPC) index [73]. The subsets containing less than five documents were excluded from further analysis. For the remaining dataset, the average number of documents in the selected subsets and the deviation from the average (Equation (1)) for each of the subsets were calculated.

$$
\delta=\frac{N_{i}-N_{\text {mean }}}{N_{\text {mean }}} \times 100 \%,
$$

where $N_{i}$ is the number of documents in the set; $N_{\text {mean }}$ is the average number of documents in the selected subsets.

The results are shown in Table 3. By aggregating the obtained results and structuring the obtained data array by enlarged clusters, it is possible to form a vector of promising directions in the field of enhanced oil recovery methods (Figure 5).

Table 3. Analysis of the sample for the period from 2010 to 2019 in accordance with the indices of the international patent classification in the field of increasing the efficiency of hydrocarbon production.

\begin{tabular}{|c|c|c|c|c|c|}
\hline \multicolumn{2}{|c|}{ Positive Dynamics } & \multicolumn{4}{|c|}{ Negative Dynamics } \\
\hline IPC & $\begin{array}{c}\text { Deviation from the } \\
\text { Average }\end{array}$ & IPC & $\begin{array}{c}\text { Deviation from the } \\
\text { Average }\end{array}$ & IPC & $\begin{array}{c}\text { Deviation from the } \\
\text { Average }\end{array}$ \\
\hline $\mathrm{E} 21 \mathrm{~B} 43 / 24$ & $832.14 \%$ & $\mathrm{E} 21 \mathrm{~B} 43 / 27$ & $-7.37 \%$ & $\mathrm{E} 21 \mathrm{~B} 28 / 00$ & $-61.40 \%$ \\
\hline $\mathrm{E} 21 \mathrm{~B} 43 / 16$ & $278.26 \%$ & $\mathrm{E} 21 \mathrm{~B} 43 / 12$ & $-7.37 \%$ & G06F17/50 & $-61.40 \%$ \\
\hline $\mathrm{E} 21 \mathrm{~B} 43 / 20$ & $266.68 \%$ & E21B43/267 & $-20.87 \%$ & C09K8/74 & $-63.33 \%$ \\
\hline $\mathrm{E} 21 \mathrm{~B} 43 / 26$ & $218.43 \%$ & E21B47/06 & $-20.87 \%$ & E21B33/138 & $-63.33 \%$ \\
\hline $\mathrm{E} 21 \mathrm{~B} 43 / 22$ & $216.50 \%$ & E21B43/14 & $-26.66 \%$ & E21B33/13 & $-65.26 \%$ \\
\hline C09K8/584 & $112.29 \%$ & $\mathrm{E} 21 \mathrm{~B} 43 / 25$ & $-30.52 \%$ & E21B43/241 & $-67.19 \%$ \\
\hline E21B43/00 & $42.81 \%$ & E21B43/243 & $-32.45 \%$ & $\mathrm{C} 09 \mathrm{~K} 8 / 80$ & $-67.19 \%$ \\
\hline C09K8/588 & $29.30 \%$ & С09K8/594 & $-36.31 \%$ & C09K8/72 & $-69.12 \%$ \\
\hline E21B49/00 & $23.51 \%$ & $\mathrm{E} 21 \mathrm{~B} 41 / 00$ & $-38.24 \%$ & C10G33/04 & $-71.05 \%$ \\
\hline $\mathrm{E} 21 \mathrm{~B} 43 / 30$ & $13.86 \%$ & C09K8/58 & $-40.17 \%$ & B01D17/04 & $-72.98 \%$ \\
\hline E21B47/00 & $10.00 \%$ & E21B7/04 & $-42.10 \%$ & C09K8/54 & $-76.84 \%$ \\
\hline C09K8/592 & $4.21 \%$ & $\mathrm{E} 21 \mathrm{~B} 36 / 00$ & $-42.10 \%$ & C09K8/582 & $-80.70 \%$ \\
\hline- & - & $\mathrm{E} 21 \mathrm{~B} 43 / 40$ & $-45.96 \%$ & C06D5/06 & $-84.56 \%$ \\
\hline- & - & E21B34/06 & $-45.96 \%$ & E21B43/263 & $-84.56 \%$ \\
\hline- & - & C09K8/60 & $-49.82 \%$ & E21B34/14 & $-86.49 \%$ \\
\hline- & - & E21B43/34 & $-53.68 \%$ & E21B43/08 & $-88.42 \%$ \\
\hline- & - & C09K8/68 & $-53.68 \%$ & E21B47/10 & $-88.42 \%$ \\
\hline- & - & E21B36/04 & $-53.68 \%$ & E21B47/12 & $-90.35 \%$ \\
\hline- & - & E21B43/18 & $-57.54 \%$ & - & - \\
\hline
\end{tabular}




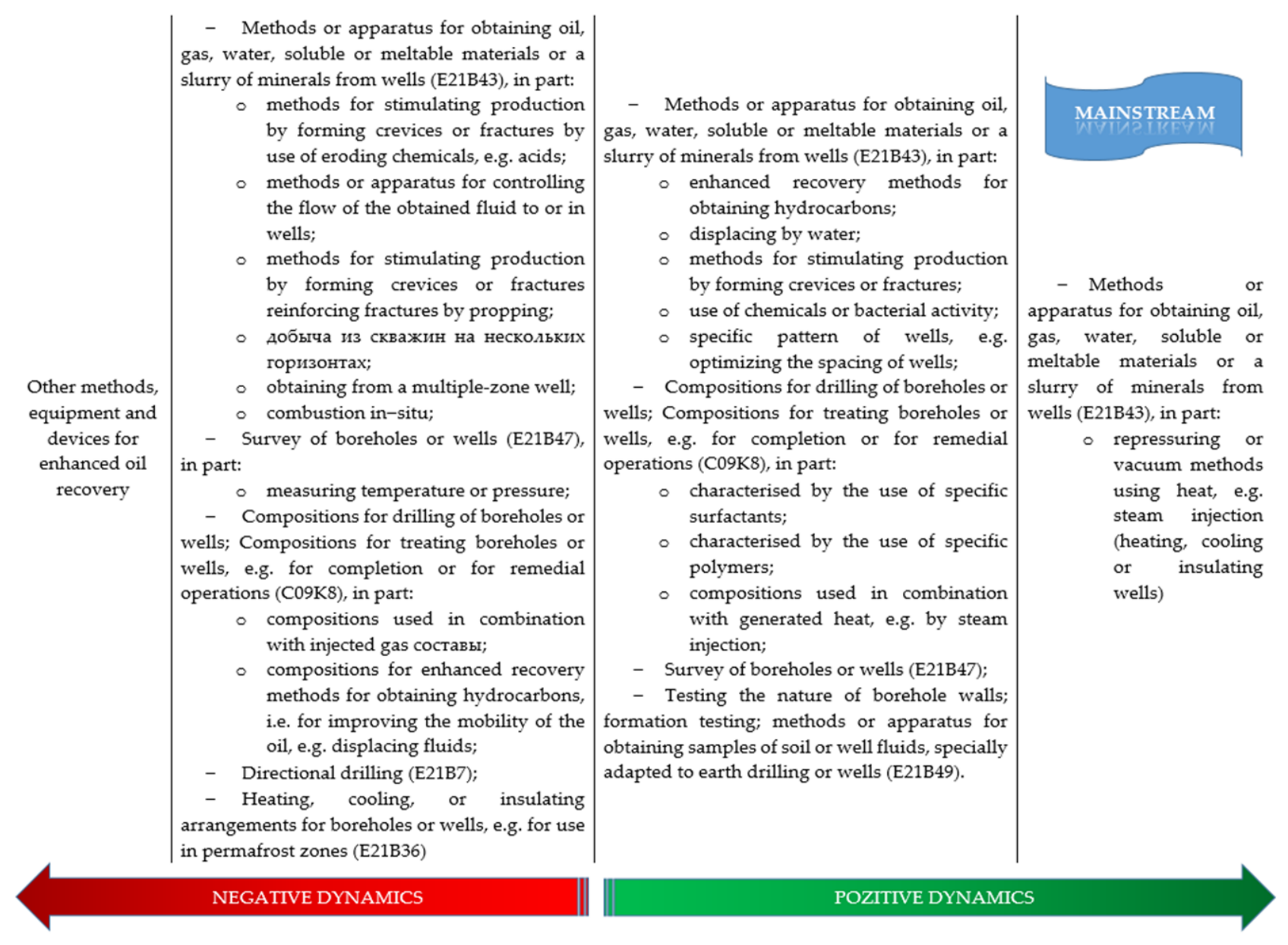

Figure 5. The mainstream technologies in the field of enhanced oil recovery methods.

\section{Main Companies Holding Patents in the Field of Enhanced Oil Recovery and the Structure of Their Patents}

Table 4 shows data on the dynamics of patent activity of the nine leading companies. The leader in the field of enhanced oil recovery methods by a significant margin is the Russian company PJSC Tatneft. The Russian company Tatneft and the Chinese company Sinopec are the most active during the entire period. In recent years, Gazpromneft STC LLC (due to registration of certificates for computer programs) and Saudi Arabian Oil CO have been increasing their publication activity.

Table 4. Dynamics of patent activity of leading companies in the field of hydrocarbon production.

\begin{tabular}{|c|c|c|c|c|c|c|c|c|c|c|c|c|}
\hline Company & 2010 & 2011 & 2012 & 2013 & 2014 & 2015 & 2016 & 2017 & 2018 & 2019 & 2020 & Total \\
\hline Tatneft & 7 & 6 & 16 & 15 & 21 & 23 & 17 & 21 & 11 & 17 & 15 & 169 \\
\hline Sinopec & 1 & 1 & 1 & 5 & 18 & 23 & 11 & 15 & 10 & 16 & 9 & 110 \\
\hline PetroChina Co Ltd. & - & - & 8 & 7 & 2 & 9 & 10 & 3 & 11 & 12 & 2 & 64 \\
\hline Saudi Arabian Oil Co & 1 & 1 & 2 & 4 & 3 & 3 & 4 & 3 & 6 & 13 & 10 & 50 \\
\hline Gazpromneft STC & - & - & 1 & 1 & 2 & 2 & 3 & 1 & 6 & 14 & 13 & 43 \\
\hline ConocoPhillips Co & 4 & 4 & 4 & 4 & 8 & 5 & - & 3 & 6 & 1 & - & 39 \\
\hline Rosneft & - & - & - & 8 & 2 & 3 & 1 & 11 & 3 & 7 & 1 & 36 \\
\hline PJSC Lukoil & 3 & 2 & 2 & 1 & $\overline{4}$ & 9 & 5 & 3 & 3 & 1 & 1 & 34 \\
\hline BASF SE & - & 10 & 2 & 1 & 2 & 2 & 1 & 2 & 2 & 4 & 5 & 31 \\
\hline
\end{tabular}




\subsection{PJSC Tatneft}

PJSC Tatneft ranks fifth in Russia in terms of oil production. According to the rating of the media holding "expert", it was ranked 15th in terms of product sales in 2016 among Russian companies.

The main assets of the company are located on the territory of the Republic of Tatarstan, and business projects are conducted in the domestic and foreign markets. Tatneft works at 77 oil fields, the largest of which is Romashkinskoye.

Proven oil reserves as of 31 December 2016 are 872.3 million tons. Tatneft produces the most "expensive" and the most "complicated" oil in Russia at a cost of $\$ 50$ per barrel (as of 2008).

During the period 2010-2020, PJSC Tatneft and its subsidiaries selected 170 patents describing inventions in the field of enhanced oil recovery methods.

Patents can be divided into several groups by enhanced oil recovery methods: seismoacoustic impact (1 patent); gas method for increasing oil recovery (2 patents); mathematical modeling in the field of oil production ( 2 patents); gas generators ( 9 patents); physical and chemical methods for increasing oil recovery (11 patents); chemical methods for increasing oil recovery (22 patents); hydraulic fracturing (32 patents); flooding (38 patents); and thermal enhanced oil recovery methods (52 patents). Most of the patents relate to thermal enhanced oil recovery methods.

\subsection{China Petroleum \& Chemical Corporation (Sinopec)}

China Petroleum \& Chemical Corporation (Sinopec Group) is one of the largest Chinese state-owned companies. For the period 2010-2020, 110 Sinopec patents registered with English-language patent offices and describing inventions in the field of enhanced oil recovery methods were selected for analysis.

The key areas (96 patents) are the following enhanced oil recovery methods: flooding (37 patents); thermal enhanced oil recovery methods (29 patents); mathematical modeling in the field of oil production (18 patents); and physical and chemical methods of increasing oil production (12 patents).

\subsection{PetroChina}

The scope of activities includes exploration, development, and production of oil and natural gas. The company also engaged in the processing, transportation, and distribution of oil, oil products, and petrochemical products and the sale of natural gas. It is one of the largest players in the industry by market capitalization.

For the period 2010-2020, 65 PetroChina patents registered in English-language patent offices and describing inventions in the field of physical and chemical enhanced oil recovery methods were selected for analysis.

The key areas (50 patents) are the following enhanced oil recovery methods: flooding (30 patents); thermal methods for increasing oil well productivity (12 patents); and hydraulic fracturing (8 patents).

\subsection{Saudi Arabian Oil Co}

The full name of the company is Saudi Arabian Oil Company. The largest oil company in the world in terms of oil production and the size of oil reserves. It is a source of up to $80 \%$ of revenues for the budget of Saudi Arabia. According to the Financial Times, in 2006, it is the largest company in the world by business value (781 billion dollars); in 2018, Saudi Aramco made a global record profit-the company earned 111 billion dollars with total revenue of 355.9 billion dollars.

For the period 2010-2020, 50 patents of Saudi Aramco describing inventions in the field of physical and chemical enhanced oil recovery methods were selected for analysis.

The key areas (34 patents) are the following enhanced oil recovery methods: physical and chemical enhanced oil recovery methods ( 24 patents) and flooding (10 patents). 


\subsection{Gazpromneft STC LLC (Gazprom-Neft Scientific and Technical Center)}

Scientific-Technical Center of "Gazprom Neft" (LLC "Gazpromneft STC")—a subsidiary of JSC "Gazprom Neft". The main areas of work of the STC are the development of new technologies in oil production; engineering and expertise of projects for exploration and production of hydrocarbons; analysis and monitoring of oil field development and exploration; geological and hydrodynamic modeling; and technological support and operational control of drilling. Gazpromneft STC LLC is the only Russian center that combines scientific research, development of oil production technologies, and remote control of high-tech production processes. In fact, the STC combines the functions of a technology center, a research institute, and a university.

For the period 2010-2020, 39 results of intellectual activity of Gazpromneft STC LLC were selected. Of these, 31 are certificates of computer program registration, 4 are patents in the field of hydraulic fracturing for oil production, and 4 are patents in the field of mathematical modeling in oil production.

\subsection{ConocoPhillips Co}

ConocoPhillips is the third largest U.S. company by capitalization, reliable oil and gas reserves, and production, and is also the second largest by oil refining volumes. ConocoPhillips is the fifth largest company in the world (among non-state companies) in terms of reliable oil and gas reserves and the fourth largest in terms of production capacity.

For the period 2010-2020, 39 patents of ConocoPhillips Co were selected for analysis. The key area is the thermal enhanced oil recovery methods (33 patents).

\subsection{Rosteft}

Rosneft is the leader of the Russian oil industry and the world's largest public oil and gas corporation. The main activities of Rosneft are the search and exploration of hydrocarbon deposits; production of oil, gas, and gas condensate; implementation of projects for the development of offshore fields; processing of extracted raw materials; and sales of oil, gas, and their products in the territory of Russia and abroad. The company is included in the list of strategic enterprises in Russia. The main goals and objectives of Rosneft are to replenish reserves at the level of at least 100\%; the efficient production at mature fields; and its growth through the implementation of new projects, creation of new offshore production clusters, development of technologies, implementation of worldclass project management practices, monetization of gas reserves, competitive production growth, optimal configuration of refineries, and the most profitable sales of the company's products.

For the period 2010-2020, 36 results of Rosneft's intellectual activity were selected. Of these, 32 are certificates of registration of a computer program, 3 are patents in the field of hydraulic fracturing for oil production, and 1 is a patent in the field of steam-thermal impact on the reservoir.

\subsection{PJSC Lukoil}

The main activities of PJSC Lukoil and its subsidiaries are the exploration, production, processing, and sale of hydrocarbons. PJSC Lukoil is one of the largest publicly traded vertically integrated oil and gas companies in the world. As of 1 January 2020, the group's proven hydrocarbon reserves according to the United States Securities and Exchange Commission standards are 15.8 billion barrels of oil equivalent (12.0 billion barrels of oil and 22.5 trillion cubic feet of gas). The group's reserves are primarily traditional. The group conducts oil and gas exploration and production in Russia and abroad. In Russia, the main oil-producing regions are Western Siberia, Timan-Pechora, the Urals, and the Volga region. The overseas exploration and production segment includes stakes in Production Sharing Agreements (PSAs) and other projects in Kazakhstan, Azerbaijan, Uzbekistan, Romania, Iraq, Egypt, Ghana, Norway, Cameroon, Nigeria, Mexico, the Republic of the Congo, and the United Arab Emirates. Average daily production of hydrocarbons in the first quarter 
of 2020 was 2.4 million barrels of oil equivalent, with liquid hydrocarbons accounting for about $77 \%$ of production.

Patent activity in the fields of enhanced oil recovery is aimed at mechanical, physical, chemical, thermogasochemical, and thermal methods of enhanced oil recovery, as well as mathematical modeling of processes occurring during oil production.

\subsection{BASF SE}

BASF SE is the world's largest chemical concern. BASF products are used in virtually all oilfield operations, including drilling, cementing, well development and operation, and enhanced recovery (EOR).

For the period 2010-2020, 16 BASF SE patents were selected, describing inventions in the field of physical and chemical enhanced oil recovery methods. These inventions can be divided into two groups: enhanced oil recovery using surfactants and using polymer compositions.

\section{Conclusions}

Analysis of the intellectual property market in the field of enhanced oil recovery methods over the past decade has shown positive dynamics, which is primarily due to the depletion of easily recoverable oil reserves and the transition to production from low-permeability reservoirs, oil sands and bitumen, ultra-viscous oil, etc. The Russian Federation, Saudi Arabia, and the United States are identified as the leading countries, although the countries' oil resources differ significantly, which affects the structure of the main patent holders engaged in oil production in these countries.

The analysis showed that thermal enhanced oil recovery methods are mainstream. However, three companies singled out as leaders do not have patents in this sector: the BASF SE is focused on the production of chemicals, including for oil production; the Saudi Arabian Oil Company produces light oil using waterflooding and physicochemical methods; the Gazpromneft STC LLC is a subsidiary of the largest supplier of gas, and therefore, in the field of oil production, the patent portfolio is mainly filled with software.

Author Contributions: Conceptualization, D.A.S. and R.R.S.; methodology, M.G.G., A.V.O., and V.A.V. (Violetta A. Vasilenko); formal analysis, M.G.G. and A.V.O.; investigation, V.A.V. (Violetta A. Vasilenko), V.A.V. (Vasili A. Vasilenko), and E.A.S.; data curation, V.A.V. (Violetta A. Vasilenko), V.A.V. (Vasili A. Vasilenko), and E.A.S.; writing-M.G.G. and V.A.V. (Violetta A. Vasilenko); writing-review and editing, M.G.G.; visualization, M.G.G. and V.A.V. (Violetta A. Vasilenko); supervision, D.A.S., R.R.S., and A.V.O.; project administration, R.R.S. and M.G.G.; funding acquisition, D.A.S. and R.R.S. All authors have read and agreed to the published version of the manuscript.

Funding: The research was supported by the Ministry of Science and High Education of Russia Federation in the frame of grant NO. 05.601.21.0019 of 29 November 2019 (ID \# RFMEFI60119X0019).

Institutional Review Board Statement: Not applicable.

Informed Consent Statement: Not applicable.

Data Availability Statement: No new data were created or analyzed in this study. Data sharing is not applicable to this article.

Conflicts of Interest: The authors declare no conflict of interest.

\section{References}

1. Navas-Anguita, Z.; García-Gusano, D.; Iribarren, D. A review of techno-economic data for road transportation fuels. Renew. Sustain. Energy Rev. 2019, 112, 11-26. [CrossRef]

2. An, H.; Wilhelm, W.E.; Searcy, S.W. Biofuel and petroleum-based fuel supply chain research: A literature review. Biomass Bioenergy 2011, 35, 3763-3774. [CrossRef]

3. Krutof, A.; Hawboldt, K. Blends of pyrolysis oil, petroleum, and other bio-based fuels: A review. Renew. Sustain. Energy Rev. 2016, 59, 406-419. [CrossRef]

4. Lu, H.; Azimi, M. Oil and Gas 4.0 era: A systematic review and outlook. Comput. Ind. 2019, 111, 68-90. [CrossRef] 
5. Rashid, Z.; Wilfred, C.D.; Gnanasundaram, N.; Arunagiri, A.; Murugesan, T. A comprehensive review on the recent advances on the petroleum asphaltene aggregation. J. Petrol. Sci. Eng. 2019, 176, 249-268. [CrossRef]

6. Saleh, T.A. Characterization, determination and elimination technologies for sulfur from petroleum: Toward cleaner fuel and a safe environment. Trends Environ. Anal. Chem. 2020, 25, e00080. [CrossRef]

7. Tsay, C.; Pattison, R.C.; Piana, M.R.; Baldea, M. A survey of optimal process design capabilities and practices in the chemical and petrochemical industries. Comput. Chem. Eng. 2018, 112, 180-189. [CrossRef]

8. Saab, R.; Polychronopoulou, K.; Zheng, L.; Kumar, S.; Schiffer, A. Synthesis and performance evaluation of hydrocracking catalysts: A review. J. Ind. Eng. Chem. 2020, 89, 83-103. [CrossRef]

9. Fakhroleslam, M.; Sadrameli, S.M. Thermal/catalytic cracking of hydrocarbons for the production of olefins; a state-of-the-art review III: Process modeling and simulation. Fuel 2019, 252, 553-566. [CrossRef]

10. Beens, J.; Blomberg, J. Chapter 7 Petrochemistry. Compr. Anal. Chem. 2009, 55, 149-166.

11. Chen, J.; Lu, X. Progress of petroleum coke combusting in circulating fluidized bed boilers-A review and future perspectives. Resour. Conserv. Recycl. 2007, 49, 203-216. [CrossRef]

12. Absi-Halabi, M.; Stanislaus, A.; Trimm, D.L. Coke formation on catalysts during the hydroprocessing of heavy oils. Appl. Catal. 1991, 72, 193-215. [CrossRef]

13. Statistical Review of World Energy. 2020. 69th Edition. Available online: https://www.bp.com/content/dam/bp/businesssites/en/global/corporate/pdfs/energy-economics/statistical-review/bp-stats-review-2020-full-report.pdf (accessed on 24 November 2020).

14. Soeder, D.J. The successful development of gas and oil resources from shales in North America. J. Petrol. Sci. Eng. 2018, 163, 399-420. [CrossRef]

15. Castro-Alvarez, F.; Marsters, P.; Barido, D.P.L.; Kammen, D.M. Sustainability lessons from shale development in the United States for Mexico and other emerging unconventional oil and gas developers. Renew. Sustain. Energy Rev. 2018, 82, 1320-1332. [CrossRef]

16. Kang, Z.; Zhao, Y.; Yang, D. Review of oil shale in-situ conversion technology. Appl. Energy 2020, 269, 115121. [CrossRef]

17. Thomas, M.; Pidgeon, N.; Bradshaw, M. Shale development in the US and Canada: A review of engagement practice. Extr. Ind. Soc. 2018, 5, 557-569. [CrossRef]

18. OPEC Share of World Crude Oil Reserves. Available online: https://www.opec.org/opec_web/en/data_graphs/330.htm (accessed on 24 November 2020).

19. Alkhathlan, K.; Javid, M. Carbon emissions and oil consumption in Saudi Arabia. Renew. Sustain. Energy Rev. 2015, 48, 105-111. [CrossRef]

20. Ansari, D. OPEC, Saudi Arabia, and the shale revolution: Insights from equilibrium modelling and oil politics. Energy Policy 2017, 111, 166-178. [CrossRef]

21. Alnajdi, O.; Calautit, J.K.; Wu, Y. Development of a multi-criteria decision making approach for sustainable seawater desalination technologies of medium and large-scale plants: A case study for Saudi Arabia's vision 2030. Energy Procedia 2019, 158, 4274-4279. [CrossRef]

22. Alkhathlan, K.; Gately, D.; Javid, M. Analysis of Saudi Arabia's behavior within OPEC and the world oil market. Energy Policy 2014, 64, 209-225. [CrossRef]

23. Gately, D.; Al-Yousef, N.; Al-Sheikh, H.M.H. The rapid growth of domestic oil consumption in Saudi Arabia and the opportunity cost of oil exports foregone. Energy Policy 2012, 47, 57-68. [CrossRef]

24. Pfister, S.; Capo, R.C.; Stewart, B.W.; Macpherson, G.L.; Phan, T.T.; Gardiner, J.B.; Diehl, J.R.; Lopano, C.L.; Hakala, J.A. Geochemical and lithium isotope tracking of dissolved solid sources in Permian Basin carbonate reservoir and overlying aquifer waters at an enhanced oil recovery site, northwest Texas, USA. Appl. Geochem. 2017, 87, 122-135. [CrossRef]

25. Esq, P.M.M. A regulatory framework for migrating from enhanced oil recovery to carbon capture and storage: The USA experience. Energy Procedia 2011, 4, 5941-5947. [CrossRef]

26. Johnson, W.I.; Olsen, D.K.; Sarathi, P.S. Environmental factors affecting heavy oil recovery in the midcontinent (Kansas, Missouri and Oklahoma) USA. Fuel 1992, 71, 1493-1498. [CrossRef]

27. Alvarado, V.; Manrique, E. Chapter 1-Reservoir Development Plans. In Book Enhanced Oil Recovery; Gulf Professional Publishing: Houston, TX, USA, 2010; pp. 1-5.

28. Epelle, E.I.; Gerogiorgis, D.I. Adjoint-based well placement optimisation for Enhanced Oil Recovery (EOR) under geological uncertainty: From seismic to production. J. Petrol. Sci. Eng. 2020, 190, 107091. [CrossRef]

29. Speight, J.G. Heavy Oil Recovery and Upgrading; Gulf Professional Publishing: Houston, TX, USA, 2009 ; p. 821.

30. Vishnyakov, V.; Suleimanov, B.; Salmanov, A.; Zeynalov, E. Hydrocarbon and oil reserves classification. In Book Primer on Enhanced Oil Recovery; Gulf Professional Publishing: Houston, TX, USA, 2010; pp. 5-26.

31. Liao, S.; Wang, F.; Wu, T.; Pan, W. Crude oil price decision under considering emergency and release of strategic petroleum reserves. Energy 2016, 102, 436-443. [CrossRef]

32. Smith, J.L. Estimating the future supply of shale oil: A Bakken case study. Energy Econ. 2018, 69, 395-403. [CrossRef]

33. Mu, L.; Chen, Y.; Xu, A.; Wang, R. Technological progress and development directions of PetroChina overseas oil and gas field production. Petrol. Explor. Dev. 2020, 47, 124-133. [CrossRef] 
34. Jia, F.R.; Jing, W.T.; Liu, G.X.; Yue, Q.; Wang, H.M.; Shi, L. Paraffin-based crude oil refining process unit-level energy consumption and $\mathrm{CO}_{2}$ emissions in China. J. Clean. Prod. 2020, 255, 120347. [CrossRef]

35. Yang, L.; Sheng, J.J. Experimental study on the oxidation behaviors of Wolfcamp light crude oil and its saturate, aromatic and resin fractions using accelerated rate calorimetry tests. Fuel 2020, 276, 117927. [CrossRef]

36. Hamidian, R.; Lashkarbolooki, M.; Amani, H. Evaluation of surface activity of asphaltene and resin fractions of crude oil in the presence of different electrolytes through dynamic interfacial tension measurement. J. Mol. Liq. 2020, 300, 112297. [CrossRef]

37. Sakthipriya, N.; Doble, M.; Sangwai, J.S. Action of biosurfactant producing thermophilic Bacillus subtilis on waxy crude oil and long chain paraffins. Int. Biodeterior. Biodegrad. 2015, 105, 168-177. [CrossRef]

38. Bissada, K.K.A.; Tan, J.; Szymezyk, E.; Darnell, M.; Mei, M. Group-type characterization of crude oil and bitumen. Part II: Efficient separation and quantification of normal-paraffins iso-paraffins and naphthenes (PIN). Fuel 2016, 173, 217-221. [CrossRef]

39. Lashkarbolooki, M.; Ayatollahi, S. Effect of asphaltene and resin on interfacial tension of acidic crude oil/ sulfate aqueous solution: Experimental study. Fluid Phase Equilibria 2016, 414, 149-155. [CrossRef]

40. Lashkarbolooki, M.; Riazi, M.; Ayatollahi, S.; Hezave, A.Z. Synergy effects of ions, resin, and asphaltene on interfacial tension of acidic crude oil and low-high salinity brines. Fuel 2016, 165, 75-85. [CrossRef]

41. Sun, Y.; Zhang, S.; Wei, X.; Sang, G.; Zhou, M.; Huang, J.; Yang, J. The study on exploitation potential of original low-oil-saturation reservoirs. Petrol. Res. 2020, 5, 52-58.

42. Wan, T.; Wang, X.; Jing, J.; Gao, Y. Gas injection assisted steam huff-n-puff process for oil recovery from deep heavy oil reservoirs with low-permeability. J. Petrol. Sci. Eng. 2020, 185, 106613. [CrossRef]

43. Arciniegas, L.M.; Babadagli, T. Asphaltene precipitation, flocculation and deposition during solvent injection at elevated temperatures for heavy oil recovery. Fuel 2014, 124, 202-211. [CrossRef]

44. Liu, R.; Du, D.; Pu, W.; Peng, Q.; Tao, Z.; Pang, Y. Viscoelastic displacement and anomalously enhanced oil recovery of a novel star-like amphiphilic polyacrylamide. Chem. Eng. Res. Des. 2019, 142, 369-385. [CrossRef]

45. Cui, J.; Zhang, Z.; Liu, X.; Liu, L.; Peng, J. Studies on viscosity reduction and structural change of crude oil treated with acoustic cavitation. Fuel 2020, 263, 116638. [CrossRef]

46. Choi, S.; Byun, D.H.; Lee, K.; Kim, J.D.; Nho, N.S. Asphaltene precipitation with partially oxidized asphaltene from water/heavy crude oil emulsion. J. Petrol. Sci. Eng. 2016, 146, 21-29. [CrossRef]

47. Schorling, P.C.; Kessel, D.G.; Rahimian, I. Influence of the crude oil resin/asphaltene ratio on the stability of oil/water emulsions. Colloids Surf. A Physicochem. Eng. Asp. 1999, 152, 95-102. [CrossRef]

48. Ahmadi, M.; Chen, Z. Challenges and future of chemical assisted heavy oil recovery processes. Adv. Colloid Interface Sci. 2020, 275, 102081. [CrossRef] [PubMed]

49. Li, X.; Berg, S.; Castellanos-Diaz, J.; Wiegmann, A.; Verlaan, M. Solvent-dependent recovery characteristic and asphaltene deposition during solvent extraction of heavy oil. Fuel 2020, 263, 116716. [CrossRef]

50. Marquez, S.G.; Ghafoori, S.; Omar, M.; Almarshed, A. Delineation of most efficient recovery technique for typical heavy oil reservoir in the Middle East region through compositional simulation of temperature-dependent relative permeabilities. J. Petrol. Sci. Eng. 2020, 186, 106725. [CrossRef]

51. Askarova, A.; Turakhanov, A.; Markovic, S.; Popov, E.; Maksakov, K.; Usachev, G.; Karpov, V.; Cheremisin, A. Thermal enhanced oil recovery in deep heavy oil carbonates: Experimental and numerical study on a hot water injection performance. J. Petrol. Sci. Eng. 2020, 194, 107456. [CrossRef]

52. Liu, Y.; Liu, X.; Hou, J.; Li, H.I.; Liu, Y.; Chen, Z. Technical and economic feasibility of a novel heavy oil recovery method: Geothermal energy assisted heavy oil recovery. Energy 2019, 181, 853-867. [CrossRef]

53. Guo, K.; Li, H.; Yu, Z. In-situ heavy and extra-heavy oil recovery: A review. Fuel 2016, 185, 886-902. [CrossRef]

54. Zhou, X.; Yuan, Q.; Peng, X.; Zeng, F.; Zhang, L. A critical review of the $\mathrm{CO}_{2}$ huff ' $\mathrm{n}$ ' puff process for enhanced heavy oil recovery. Fuel 2018, 215, 813-824. [CrossRef]

55. Umar, A.A.; Saaid, I.B.M.; Sulaimon, A.A.; Pilus, R.B.M. A review of petroleum emulsions and recent progress on water-in-crude oil emulsions stabilized by natural surfactants and solids. J. Petrol. Sci. Eng. 2018, 165, 673-690. [CrossRef]

56. Ahmadi, M.; Hou, Q.; Wang, Y.; Chen, Z. Interfacial and molecular interactions between fractions of heavy oil and surfactants in porous media: Comprehensive review. Adv. Colloid Interface Sci. 2020, 283, 102242. [CrossRef] [PubMed]

57. Foroozesh, J.; Kumar, S. Nanoparticles behaviors in porous media: Application to enhanced oil recovery. J. Mol. Liq. 2020, 316, 113876. [CrossRef]

58. Abdulredha, M.M.; Aslina, S.; Luqman, H.; Abdullah, C. Overview on petroleum emulsions, formation, influence and demulsification treatment techniques. Arab. J. Chem. 2020, 13, 3403-3428. [CrossRef]

59. Corredor, L.M.; Husein, M.M.; Maini, B.B. A review of polymer nanohybrids for oil recovery. Adv. Colloid Interface Sci. 2020, 272, 102018. [CrossRef]

60. Zolfaghari, R.; Fakhru'l-Razi, A.; Abdullah, L.C.; Elnashaie, S.S.E.H.; Pendashteh, A. Demulsification techniques of water-in-oil and oil-in-water emulsions in petroleum industry. Sep. Purif. Technol. 2016, 170, 377-407. [CrossRef]

61. Li, L.; Huang, W.; Zhou, C.; Chen, Y. Advances on the transition-metal based catalysts for aquathermolysis upgrading of heavy crude oil. Fuel 2019, 257, 115779. [CrossRef]

62. Alhammadi, A.M.; Gao, Y.; Akai, T.; Blunt, M.J.; Bijeljic, B. Pore-scale X-ray imaging with measurement of relative permeability, capillary pressure and oil recovery in a mixed-wet micro-porous carbonate reservoir rock. Fuel 2020, 268, 117018. [CrossRef] 
63. Khalilinezhad, S.S.; Mohammadi, A.H.; Hashemi, A.; Ghasemi, M. Rheological characteristics and flow dynamics of polymer nanohybrids in enhancing oil recovery from low permeable carbonate oil reservoirs. J. Petrol. Sci. Eng. 2020. [CrossRef]

64. Heydari-Farsani, E.; Neilson, J.E.; Alsop, G.I.; Hamidi, H. The effect of rock type on natural water flooding and residual oil saturation below free water level and oil water contact: A case study from the Middle East. J. Petrol. Sci. Eng. 2020, 193, 107392. [CrossRef]

65. Li, S.; Lu, C.; Wu, M.; Hu, Z.; Li, Z.; Wang, Z. New insight into $\mathrm{CO}_{2}$ huff-n-puff process for extraheavy oil recovery via viscosity reducer agents: An experimental study. J. $\mathrm{CO}_{2}$ Util. 2020, 42, 101312. [CrossRef]

66. Louhenapessy, S.C.; Ariadji, T. The effect of type waves on vibroseismic implementation of changes properties of rock, oil viscosity, oil compound composition, and enhanced oil recovery. Petrol. Res. 2020, 5, 304-314. [CrossRef]

67. Liu, Z.; Wu, G.; Wei, C. Physical experiments and numerical simulations of viscosity reducer flooding for ordinary heavy oil. J. Petrol. Sci. Eng. 2020, 192, 107194. [CrossRef]

68. Shi, L.; Liu, C.; Chen, M.; Hua, Z.; Ye, Z.; Zhang, J. Synthesis and evaluation of a hyperbranched copolymer as viscosity reducer for offshore heavy oil. J. Petrol. Sci. Eng. 2021, 196, 108011. [CrossRef]

69. European Patent Office. Available online: https://worldwide.espacenet.com/ (accessed on 24 November 2020).

70. World Intellectual Property Organization. Available online: https://www.wipo.int/portal/en/index.html (accessed on 24 November 2020).

71. Federal Institute of Industrial Property (FIPS). Available online: https:/ / www1.fips.ru/en/ (accessed on 24 November 2020).

72. Google Patents. Available online: https://patents.google.com/advanced (accessed on 24 November 2020).

73. International Patent Classification (IPC) Index. Available online: https://www.wipo.int/classifications/ipc/ipcpub/?notion= scheme\&version $=20200101 \&$ symbol=none\&menulang $=$ en\&lang $=$ en\&viewmode $=\mathrm{f} \&$ fipcpc $=$ no\&showdeleted $=$ yes \&indexes $=$ no\&headings=yes\&notes $=$ yes\&direction $=02 \mathrm{n} \&$ initial $=\mathrm{A} \& \mathrm{cwid}=$ none\&tree $=$ no\&searchmode $=$ smart $($ accessed on 24 November 2020). 